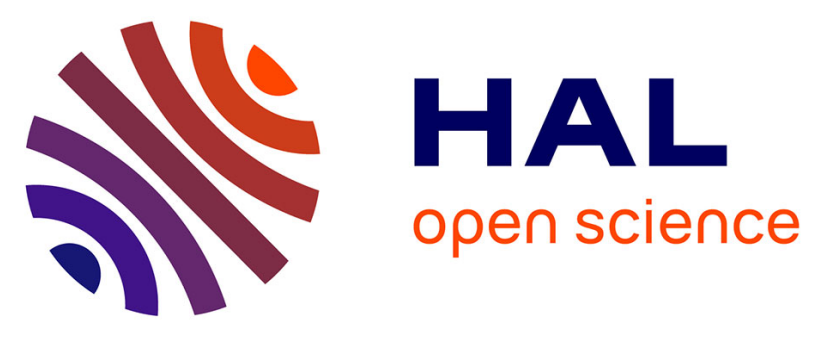

\title{
Limited thermochemical sulfate reduction in hot, anhydritic, sour gas carbonate reservoirs: The Upper Jurassic Arab Formation, United Arab Emirates
}

Daniel Morad, Fadi H. Nader, Sadoon Morad, Carlos Rossi, Marta Gasparrini, Mohammad Alsuwaidi, Fatima Al Darmaki, Helge Hellevang

\section{To cite this version:}

Daniel Morad, Fadi H. Nader, Sadoon Morad, Carlos Rossi, Marta Gasparrini, et al.. Limited thermochemical sulfate reduction in hot, anhydritic, sour gas carbonate reservoirs: The Upper Jurassic Arab Formation, United Arab Emirates. Marine and Petroleum Geology, 2019, 106, pp.30-41. 10.1016/j.marpetgeo.2019.04.023 . hal-02180623

\section{HAL Id: hal-02180623 \\ https://hal-ifp.archives-ouvertes.fr/hal-02180623}

Submitted on 11 Jul 2019

HAL is a multi-disciplinary open access archive for the deposit and dissemination of scientific research documents, whether they are published or not. The documents may come from teaching and research institutions in France or abroad, or from public or private research centers.
L'archive ouverte pluridisciplinaire HAL, est destinée au dépôt et à la diffusion de documents scientifiques de niveau recherche, publiés ou non, émanant des établissements d'enseignement et de recherche français ou étrangers, des laboratoires publics ou privés. 


\title{
Limited thermochemical sulfate reduction in hot, anhydritic, sour gas carbonate reservoirs: the Upper Jurassic Arab Formation, United Arab Emirates
}

Daniel Morad, Fadi H. Nader ${ }^{\mathrm{b}}$, Sadoon Morad ${ }^{\mathrm{c}}$, Carlos Rossi ${ }^{\mathrm{d}}$, Marta Gasparrini ${ }^{\mathrm{b}}$, Mohammad Alsuwaidi ${ }^{\mathrm{c}}$, Fatima Al Darmaki ${ }^{\mathrm{e}}$, Helge Hellevang ${ }^{\mathrm{a}}$

a Department of Geosciences, University of Oslo, Pb 1047 Blindern, 0316, Oslo, Norway ${ }^{\mathrm{b}}$ IFP Energies nouvelles, 1-4 av. de Bois-Préau, 92852 Rueil-Malmaison, France

${ }^{\mathrm{c}}$ Department of Geosciences, Khalifa University of Science and Technology, P.O. Box 2533, Abu Dhabi, United Arab Emirates

${ }^{\mathrm{d} D e p a r t m e n t o ~ d e ~ P e t r o l o g i ́ a ~ y ~ G e o q u i ́ m i c a, ~ U n i v e r s i d a d ~ C o m p l u t e n s e, ~} 28040$ Madrid, Spain

${ }^{\mathrm{e}}$ ADNOC Sour Gas, P.O. Box: 44115, Abu Dhabi, United Arab Emirates

\begin{abstract}
Limited thermochemical sulfate reduction (TSR) in hot $\left(130-160^{\circ} \mathrm{C}\right)$ and anhydrite-rich sour gas reservoir carbonates of the Arab Formation (Upper Jurassic) is manifested by rare calcitization of anhydrite with slightly lower $\delta^{13} \mathrm{C}_{\mathrm{VPDB}}$ values $(-3.2$ to $-0.1 \%)$ than calcite precipitated in equilibrium with Late Jurassic seawater. Fluid inclusion microthermometry of calcite that has replaced anhydrite indicates that TSR occurred between $130^{\circ} \mathrm{C}$ and $160^{\circ} \mathrm{C}$. The lack of evidence for extensive TSR, despite the suitable current temperatures and abundant sulfates in the gas reservoir, coupled with the more common TSR-related calcite in the flanks (water zone) than crest (gas zone), indicate that: (1) gas emplacement while the reservoir was buried at shallower depth slowed down or inhibited TSR in the crest even when it subsequently reached depths where extensive TSR would occur, and (2) $\mathrm{H}_{2} \mathrm{~S}$ (up to 38 vol.\%) has migrated from the underlying Permo-Triassic and/or Jurassic sulfate-carbonate deposits. This study demonstrates that constraining the timing of hydrocarbon emplacement within the context of burial-thermal history is crucial for a better understanding of the origin of $\mathrm{H}_{2} \mathrm{~S}$ in hot, anhydrite-rich, sour gas reservoirs.
\end{abstract}


Key words: Thermochemical sulfate reduction, TSR, diagenesis, carbonate, anhydrite

\section{Introduction}

Thermochemical sulfate reduction (TSR) is a common reaction in sulfate-bearing carbonate reservoirs at temperatures of around $110-140^{\circ} \mathrm{C}$ resulting in the production of $\mathrm{H}_{2} \mathrm{~S}$ by interaction of hydrocarbons and sulfate (Krouse et al., 1988; Worden et al., 2000; Machel, 2001; Worden et al., 2004). The reaction can be envisaged as: Sulfate + hydrocarbons $\rightarrow$ calcite $+\mathrm{H}_{2} \mathrm{~S}$ ( \pm water $\pm \mathrm{CO}_{2} \pm \mathrm{S} \pm$ altered hydrocarbons). The required minimum temperatures and other parameters (e.g. hydrocarbon composition, wettability) controlling the extent of TSR across hydrocarbon fields are still debated topics (Worden et al., 1996; 1998; Machel, 1998; Worden et al., 2004). In addition to the formation of hazardous $\mathrm{H}_{2} \mathrm{~S}$, TSR results also in a decrease in reserve volume (Worden and Smalley, 1996; Heydari, 1997; Machel, 2001) and may also improve reservoir quality (Hill, 1995; Ma et al., 2007; Morad et al., 2012; Jiang et al., 2018). Therefore, constraining the origin and distribution of TSR in carbonate reservoirs has important implications for hydrocarbon exploration and production.

The studied anhydrite-rich Upper Jurassic Arab Formation is a major reservoir in several oil and sour gas fields in Abu Dhabi, United Arab Emirates (UAE; Fig. 1A, B). Locally, the $\mathrm{H}_{2} \mathrm{~S}$ reaches up to 38 vol.\% of produced reservoir fluids (Nederlof et al., 2016) imposing a challenge for hydrocarbon production. The extent of TSR and origin of $\mathrm{H}_{2} \mathrm{~S}$ are not yet fully explored in these reservoirs (Morad et al., 2012; Nederlof et al., 2016). This study uses integrated analyses (petrography, isotope, fluid inclusion microthermometry and Raman spectroscopy) of diagenetic minerals in the Arab Formation reservoir from four wells in order to constrain: (1) timing, extent, conditions and distribution of TSR; and (2) why TSR is limited while the $\mathrm{H}_{2} \mathrm{~S}$ concentrations are high. 


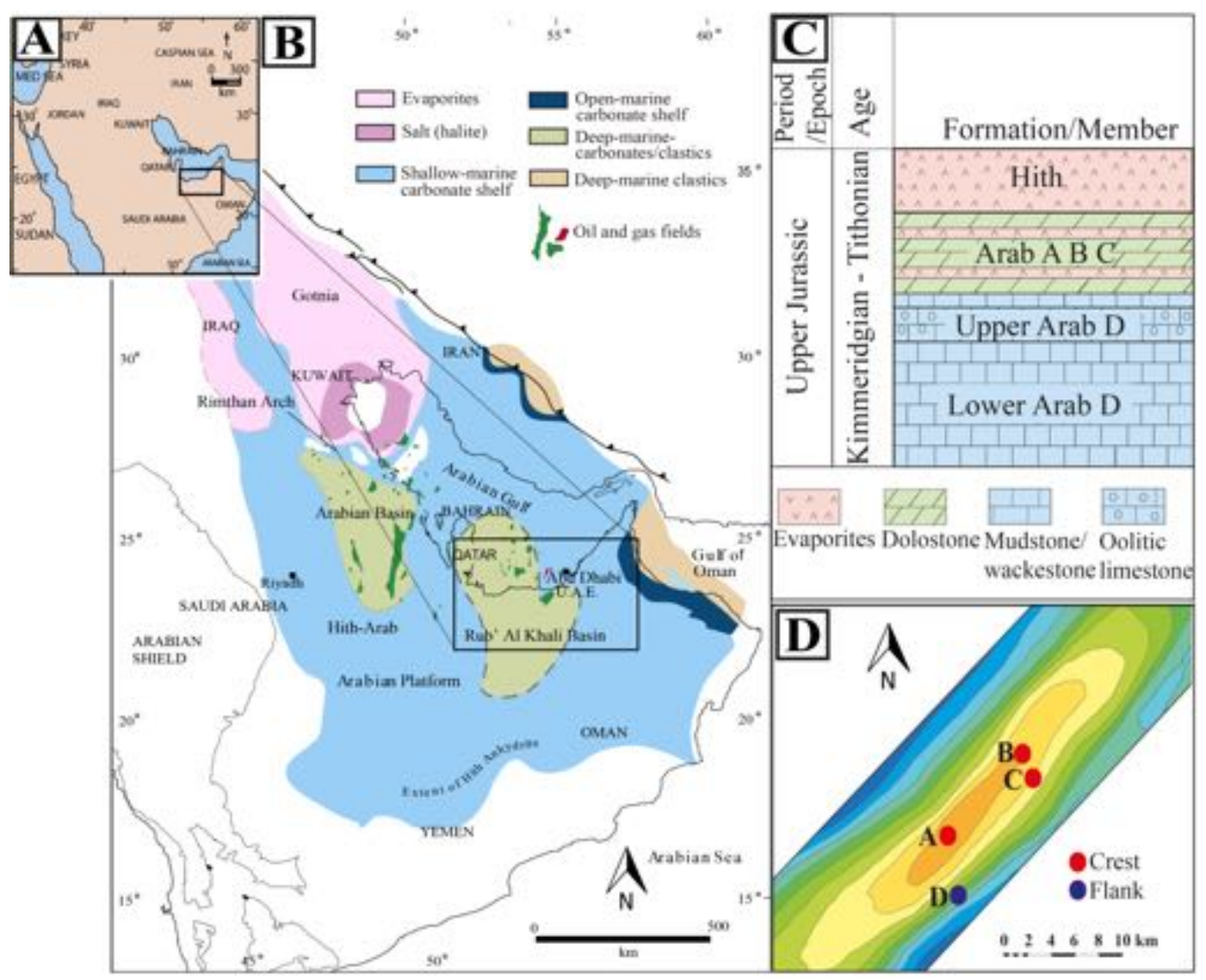

Figure 1. (A) Small-scale map of the Arabian Peninsula. (B) Late Jurassic depositional environments of the Arab and Hith formations (modified after Ziegler, 2001) showing the location of the studied field and several other oil and gas fields onshore and offshore UAE. (C) Simplified stratigraphy of the Arab Formation onshore Abu Dhabi (Morad et al., 2018). (D) Map of the studied anticline showing the sampled wells in the crest (A, B and C) and flank (D).

\section{Geological setting}

The shallow-water marine platform deposits of the Arab Formation (Kimmeridgian to Tithonian) in Abu Dhabi hydrocarbon fields are composed of carbonates and intercalated anhydrite deposits (Fig. 1C; Morad et al., 2012; Marchionda et al., 2018; Morad et al., 2018). 
The Arab Formation in the studied field can be subdivided, from bottom to top, into Arab D (lower and upper D) and C-B-A members (Fig. 1C). Limestones of the lower Arab D Member in the studied field are dominated by dark grey, bioturbated massive mudstones and wackestones that are intercalated with floatstones, which are rich in skeletal fragments (bivalves, gastropods, foraminifera, algae) and mud intraclasts (Marchionda et al., 2018). The mudstones and wackestones were deposited in an outer ramp environment and the floatstones represent storm events (Marchionda et al., 2018). The upper Arab D is composed dominantly of cross or parallel laminated or massive grainstones and packstones (Lawrence et al., 2015; Marchionda et al., 2018). The allochems in the limestones include ooids, peloids, and bioclasts. Deposition of these limestones presumably occurred in shoal and mid ramp environments (Lawrence et al., 2015; Marchionda et al., 2018). The Arab A-B-C members comprise dominantly dolostones and intercalated anhydrites at the top and lime mudstones and wackestones at the base. In the studied field (Fig. 1), cores from Arab A-B-C members were limited to lagoon environment in the anticline flank well. Deposition of anhydrites and associated mudstones (now dolomitized) is interpreted to have occurred in hypersaline lagoon and sabkha settings (i.e. supratidal and lagoon environments; Alsharhan, 1989). The dolostones, which are strongly bioturbated, have mainly mudstones and wackestones precursors. The limestones in the Arab A-B-C members are composed mainly of algal laminated and bioturbated mudstones, wackestones and packstones. These limestones have possibly been deposited in a low energy subtidal lagoon and/or in an intertidal flat (Marchionda et al., 2018). The overlying evaporite dominated Hith Formation (Fig. 1C) is the main seal in the area (Alsharhan and Scott, 2000).

The studied field consists of a gently dipping and elongated anticline (Fig. 1D) that belongs to a series of structural traps that are characterized by NE-SW alignments of fold axes. The anticline was presumably a result of the oblique movement that occurred along a 
basement fault that was reactivated during the obduction of Semail ophiolites and later collision of Arabia with Iranian Plate (Koyi et al., 2015). The field is situated on the NE part of the Arabian Plate, SW of Abu Dhabi. The measured bottom hole temperatures in the crest and flank of the anticline are around $140^{\circ} \mathrm{C}$ and $160^{\circ} \mathrm{C}$, respectively, indicating that the present day geothermal gradient is around $38^{\circ} \mathrm{C} / \mathrm{km}$.

The Diyab and Hanifa formations have been proposed as source rocks for the Upper Jurassic reservoirs in the UAE (Alsharhan and Scott, 2000). The Diyab Formation (early Late Jurassic) reached the phase of maximum oil generation in onshore areas of Abu Dhabi during the Early Eocene, whereas the organic-rich Hanifa Formation (early Upper Jurassic) entered the oil generation window during Middle Cretaceous (Ayoub and En Nadi, 2000).

A few studies have previously addressed the diagenesis of the Arab Formation in Abu Dhabi fields (Morad et al., 2012; Nader et al., 2013; Hollis et al., 2017; Morad et al., 2018). However, no studies have focused on the diagenesis related to TSR. The diagenesis in the Arab Formation includes dolomitization of limestones (sabkha and reflux models; Morad et al., 2012) and associated precipitation of anhydrite, calcite associated with dissolution of micritized allochems and stylolitization of the host limestones, burial diagenetic precipitation of sulfates and cementation (mainly saddle dolomite, fluorite and calcite) related to hot basinal brines (Morad et al., 2018).

\section{Material and methods}

Three hundred and fifty samples were collected from a total of $420 \mathrm{~m}(1377 \mathrm{ft})$ studied cores covering the Arab Formation from four wells in the crest and flank of the anticline (Fig. 1D). Transmitted-light, cathodoluminescence (CL), fluorescence, and backscattered electron microscopy were performed on polished thin sections, which were vacuum impregnated with 
blue epoxy and stained with alizarin red $\mathrm{S}$ and potassium ferricyanide in order to distinguish dolomite from calcite and determine qualitatively their iron content. The abundance and textural types of anhydrite and calcite were quantified by point counting on 500 points with JMicroVision (Roduit, 2005) on fifty selected scanned thin sections. A Technosyn MK2 system and an OPEA system (OPEAFrance) were used for the CL analyses, operating at 10$15 \mathrm{kV}$ gun potential and 300-500 $\mathrm{AA}$. Gold-palladium covered broken surfaces and carbon coated thin sections were examined with a scanning electron microscope (SEM; FEI Quanta 200 with an acceleration voltage of $30 \mathrm{kV}$ ) equipped with an Energy Dispersive X-ray Spectrometer.

A computer-automated micro-mill mounted on a binocular microscope and a dentaldrill were used to micro-sample carbonate and sulfate minerals for oxygen, carbon, sulfur and strontium isotope analyses. Contamination by host rock and other phases cannot be ruled out in some cases. Carbon and oxygen isotopes were analyzed for sixty-four samples. The evolved gas $\left(\mathrm{CO}_{2}\right)$ was analyzed using a Delta-plus mass spectrometer (University of Windsor, Canada). The isotopic data are presented in $\delta$-notation and reported in per mil (\%) relative to the V-PDB standard. The precision of carbon and oxygen isotope values is better than $0.05 \%$. The ratio of ${ }^{87} \mathrm{Sr} /{ }^{86} \mathrm{Sr}$ isotopes was obtained for two calcite and five sulfate samples by using an automated Finnigan 261 mass spectrometer equipped with nine Faraday collectors (Ruhr-Universität Bochum, Germany). Correction for isotopic fractionation during the analyses was made by normalization to ${ }^{86} \mathrm{Sr} /{ }^{88} \mathrm{Sr}=0.1194$. The mean standard error of mass spectrometer performance was \pm 0.00003 for standard NBS-987. Sulfur isotope ratios were analyzed for twenty-six sulfate samples and the $\delta^{34} \mathrm{~S}$ values are reported in \%o relative to CDT. Solid samples were analyzed for sulfur on a Costech Elemental Analyzer (CHNS-O ECS 4010-Italy) coupled to an Isochrom Continuous Flow Stable Isotope Ratio Mass Spectrometer (GVI/Micromass-UK, 1995; University of Waterloo, Canada). Sulfate samples 
are corrected by using $\mathrm{BaSO}_{4}$ standards NBS-127, EIL-42 and EIL-41 ( $\left.\mathrm{PbSO}_{4}\right)$. The error for such clean $\mathrm{BaSO}_{4}$ standard material is $\pm 0.3 \%$ for sulfur.

Aqueous fluid inclusions (FI) in diagenetic calcite and anhydrite were analyzed in seven unstained wafers, which were prepared without inducing substantial sample heating. Special emphasis was made on identifying fluid inclusion assemblages (FIA), i.e. the most finely discriminated groups of petrographically associated fluid inclusions (Goldstein and Reynolds, 1994). CL and BSE imaging proved to be instrumental in determining the origin of the fluid inclusions, by revealing possible relationships to zoning patterns, solid inclusions, or microfractures. Microthermometry, including homogenization temperatures $\left(T_{h}\right)$, and the first (apparent eutectic temperature $\left(\mathrm{T}_{\mathrm{e}}\right)$ and final ice melting temperatures $\left(\mathrm{T}_{\mathrm{m}}(\mathrm{ice})\right)$, was performed using a Linkam MDS 600 heating-freezing stage coupled with a Nikon LV100 Eclipse combined with a UV-light device (IFPEN, France). The thermocouple was calibrated with synthetic fluid inclusions $\left(\mathrm{H}_{2} \mathrm{O}, \mathrm{H}_{2} \mathrm{O}-\mathrm{NaCl}\right.$ and $\left.\mathrm{CO}_{2}\right)$. The Linksys 32 software was used to run the operations for fluid inclusion microthermometry. The total salinity is expressed as $\mathrm{wt} \% \mathrm{NaCl}$ eq. and was calculated from $\mathrm{T}_{\mathrm{m}}$ (ice) by using the Bodnar (1993) equation. Heating was performed prior to freezing in order to prevent fluid inclusion reequilibration. These measurements were obtained in the order of increasing $T_{h}$ (with a precision of $0.5^{\circ} \mathrm{C}$ ) using a calibrated Linkam THMSG 600 stage and low heating rates. Pressure correction was not applied to the measured homogenization temperatures $\left(T_{h}\right)$ and the reported $T_{h}$ should, if nothing else is stated, be regarded as minimum trapping temperatures.

In two selected samples containing nodular calcite, additional detailed FI petrography was performed on unstained wafers using an Olympus BX51 microscope equipped with UV epi-illumination, and a CITL MK5 cathodoluminescence device operating at $15 \mathrm{kV}$ and 200 $\mu \mathrm{A}$. After graphite coating, the polished sections were examined by backscattered electron (BSE) mode using a JEOL JXA-8900 electron microprobe (EMP) at the Complutense 
University, Madrid, Spain. The EMP was also used to analyze the composition of mineral inclusions using wavelength-dispersive spectrometry.

Representative fluid inclusions were analyzed in order to detect the types of gas by using a HORIBA Jobin-Yvon LabRAM HR confocal Raman microspectrometer (Eötvös University, Hungary). For the measurements we applied $532 \mathrm{~nm}$ emission of a frequencydoubled Nd:YAG laser with a grating of 1800 grooves mm-1. The maximum laser power incident on the sample was c. $40 \mathrm{~mW}$. The detected phases were identified by their characteristic Raman peaks. A $100 \times$ microscope objective was used to focus the laser onto the sample and to collect the Raman signal. Spectra were gathered 2-10× accumulations and 2$150 \mathrm{~s}$ acquisition time (all depending on the maximum intensity). Raw data were processed using LabSpec v5.25.15 software designed for Jobin-Yvon Horiba LabRam instruments.

Porosity and permeability data were obtained by a contractor for 882 core plugs (diameter of $3.8 \mathrm{~cm}$ ) from the four wells. Prior to measurements, the core plugs were examined for microfractures, cleaned by oil extractor and dried in a vacuum oven at $60^{\circ} \mathrm{C}$ for 24 hours. A helium porosimeter was used for porosity measurements and the permeability was measured by helium permeameter by applying 0.689 to $2.76 \mathrm{MPa}$.

\section{Results}

\subsection{Sulfate fabric and crystal habit}

Sulfate minerals with various crystal habits and fabric occur in four depositional facies: (i) Anhydrite nodules and beds are most common in the supratidal/sabkha and intertidal facies (up to $100 \%$ anhydrite). These anhydrites are composed of parallel and subparallel lath-shaped and felted crystals that are separated by or float in fine-crystalline 
dolomite (50-500 $\mu \mathrm{m}$ long and 10-20 $\mu \mathrm{m}$ wide; Fig. 2A). The anhydrite nodules are, in some cases, composed of coarser crystals (typically 50-500 $\mu \mathrm{m}$ long and 50-300 $\mu \mathrm{m}$ wide; Fig. 2A). These types of anhydrites were analyzed only in the crest of the anticline because cores from these depositional facies were not available in the flank. However, high bulk density log response indicates that anhydrite is present in the supratidal facies of the flank as well. (ii) Anhydrite associated with dolostone beds (0-50\% anhydrite) and limestones (0-30\% anhydrite) are common in the lagoon facies. Poikilotopic anhydrite engulfs dolomite crystals in the dolostones (Fig. 2B). Anhydrite and minor amounts of celestine occur as lath-shaped crystals $(300-3500 \mu \mathrm{m})$ that replace the lagoon limestones (1-2 mm; Fig. 2C). Celestine but no anhydrite was observed in the flank (Fig. 3B). However, cores from the lagoon facies were mainly available from the crest. (iii) Rare anhydrite $(0-2 \% ; 1-2 \mathrm{~mm})$ that enclose allochems in host grainstones (Fig. 2D) in the shoal facies on the crest. (iv) Anhydrite and celestine (0$25 \%$ ) nodules and crystals that replaced host limestone (Fig. 2E, F) were observed in the outer ramp facies in cores from the crest. These anhydrite nodules consist of medium to large sized tabular crystals (20-500 $\mu \mathrm{m}$ long, 50-400 $\mu \mathrm{m}$ wide; Fig. 2E). 

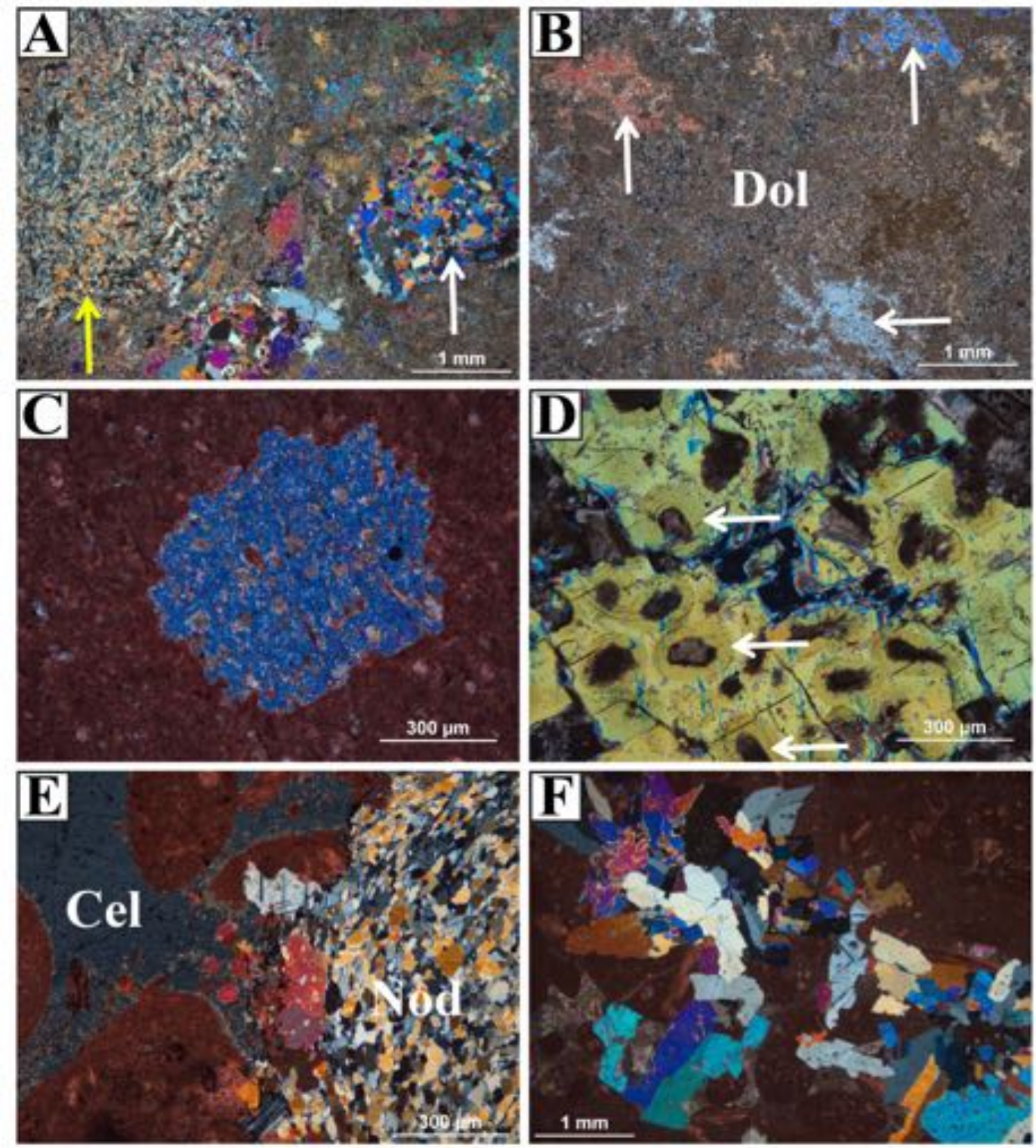

Figure 2. Photomicrographs (XPL) showing anhydrite and celestine in the Arab Formation.

(A) Anhydrite nodules in supratidal dolomicrite. Some nodules are composed of fine crystals (yellow arrow) while others by coarse crystals (white arrow). (B) Poikilotopic anhydrite cements (arrows) engulfing dolomite crystals (Dol) in lagoon facies. (C) Replacive coarse anhydrite crystal are often scattered in the lagoon mudstone facies. (D) Anhydrite crystals that have cemented intergranular pores and replaced ooids (arrows) in a shoal grainstone; note the presence of relict concentric lamellae of the replaced ooids. (E) Celestine cement (Cel) and anhydrite nodule (Nod) in outer ramp mudstone. (F) Replacive anhydrite crystals in outer ramp wackestone. 


\subsection{Nodular, tabular and blocky calcite cements}

Aggregates of fine to blocky ( $5 \mu \mathrm{m}$ up to $2 \mathrm{~mm}$ ) calcite crystals are observed within anhydrite and, less commonly, celestine nodules and cement (Fig. 3, 4). Calcite within sulfate crystals and nodules are more common at the edges than in the centers of these sulfate phases (Fig. 3C, G, 4C, D). The anhydrite is locally partly dissolved when observed in close relationship with calcite (Fig. 4E). Nodular, tabular and blocky calcites are more common in the outer ramp than in the supratidal and lagoon facies (Fig. 3, 4). Minor amounts of such calcite are observed in the shoal facies on the flank of the anticline (Fig. 3F). Tiny remnants of anhydrite within calcite cement were observed in the outer ramp facies in the flank (Fig. $3 \mathrm{H} ;<1 \%$ of the rock volume), while a few celestine crystals associated without any or only small amounts of calcite were observed in the lagoon facies in the flank (Fig. 3B).

Figure 3. Photomicrographs comparing the intimate association of sulfate and calcite in the various depositional facies from the crest and flank. (A) Anhydrite nodules (Anh) separated by dolomicrite (Dol) in supratidal/sabkha facies (crest; PPL). (B) Same photomicrographs as in (A) with XPL. Cores from the supratidal/sabkha facies from the flank were not available in this study. However, bulk density logs suggest that anhydrite is present here too. (C) Minor calcite (Cal) is observed along the outer rim of anhydrite cement (Anh) in a partly dolomitized (Dol) mudstone from the lagoon facies (crest; PPL). (D) Minor calcite (white arrow) engulfing celestine crystals (Cel) in the lagoon facies (flank; PPL). (E) Anhydrite (Anh) enclosing calcite cement and allochems in a shoal grainstone (crest; PPL). (F) Calcite cement (Cal) and saddle dolomite (SD) in the shoal facies (flank; PPL). (G) Calcite (Cal) that 
is enclosing anhydrite cement (Anh) in the outer ramp facies (crest; PPL). (H) Tabular calcite in the outer ramp facies. Small remnants of anhydrite (arrows) are observed within this calcite. Saddle dolomite (SD) is observed in close association with the tabular calcite (flank; PPL).
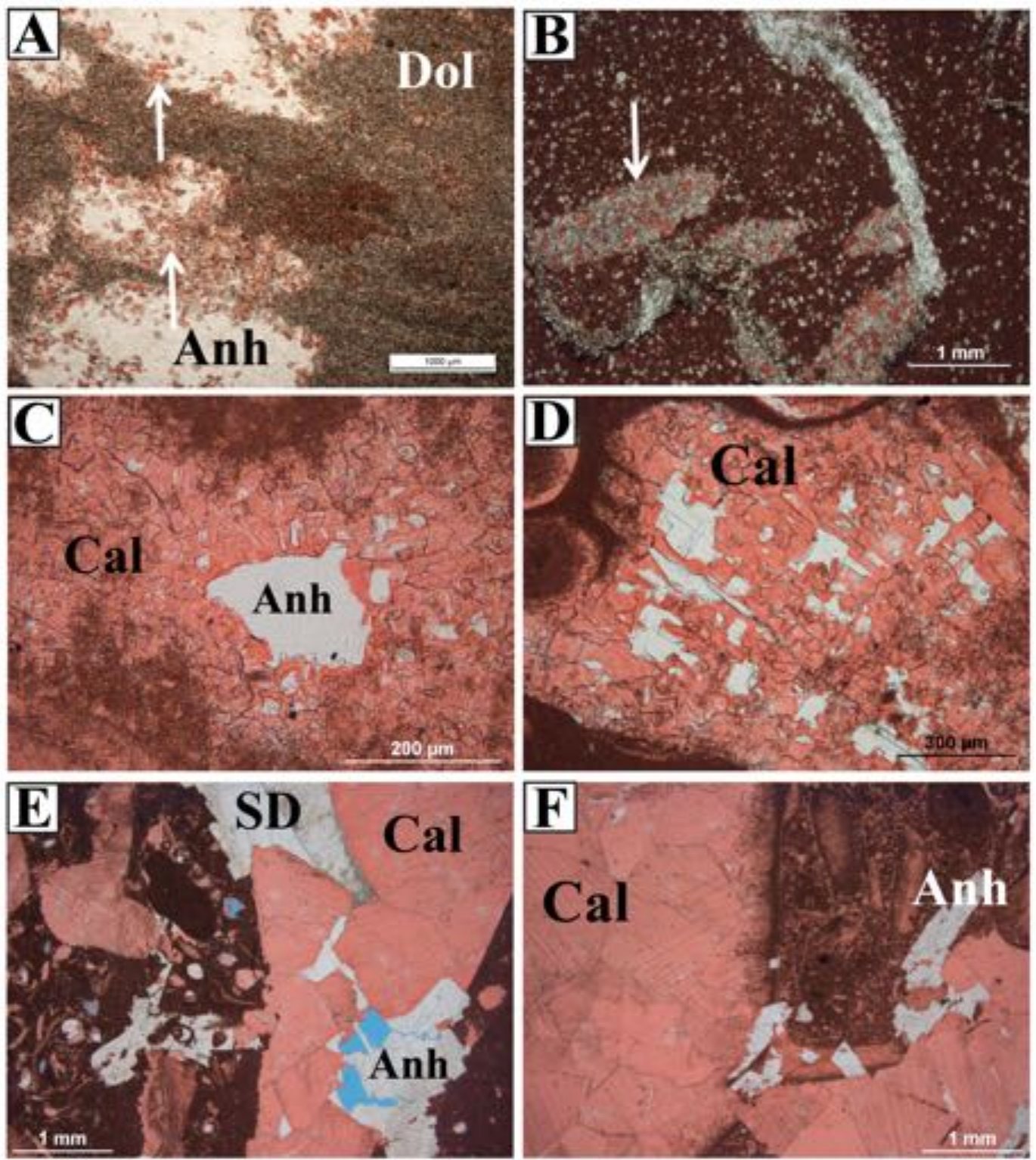

Figure 4. Photomicrographs (PPL) of calcite (Cal; stained red by alizarin red) in close relationship with anhydrite on the crest of the anticline. (A) Calcite concentrated mainly along the edges of the anhydrite nodules (arrow) in a partly dolomitized mudstone (outer ramp facies). (B) Partly dolomitized calcite crystals in the lagoon facies. (C) and (D) Calcite 
engulfing anhydrite cements (Anh). Note that calcite is more common at the edges of the anhydrite. (E) and (F) Coarse crystalline calcite engulfing anhydrite cement (Anh); note the partial dissolution of the anhydrite (E; blue color). Saddle dolomite (SD) is often associated with the calcite.

The margins of anhydrite nodules locally contain tabular calcite crystals (Fig. 5A). The calcite in anhydrite nodules is non-fluorescent, dull brownish mottled to homogeneous CL (Fig. 5B), and contains abundant, relatively large $(\sim 10-100 \mu \mathrm{m})$ presumably primary biphase aqueous inclusions (Fig. 5B, C), which are associated with dolomite and rare anhydrite inclusions (Fig. 5D, E). Saddle dolomite is locally engulfed by the calcite, especially along the margins of calcite nodules. Small (1-10 $\mu \mathrm{m}$ wide) discrete pyrite crystals are observed in close association with nodular and tabular calcite.

It was not possible to compare the presence/abundance of nodular and tabular shaped in the supratidal and lagoon facies between crest and flank because cores from these facies were not available or limited in the flank.

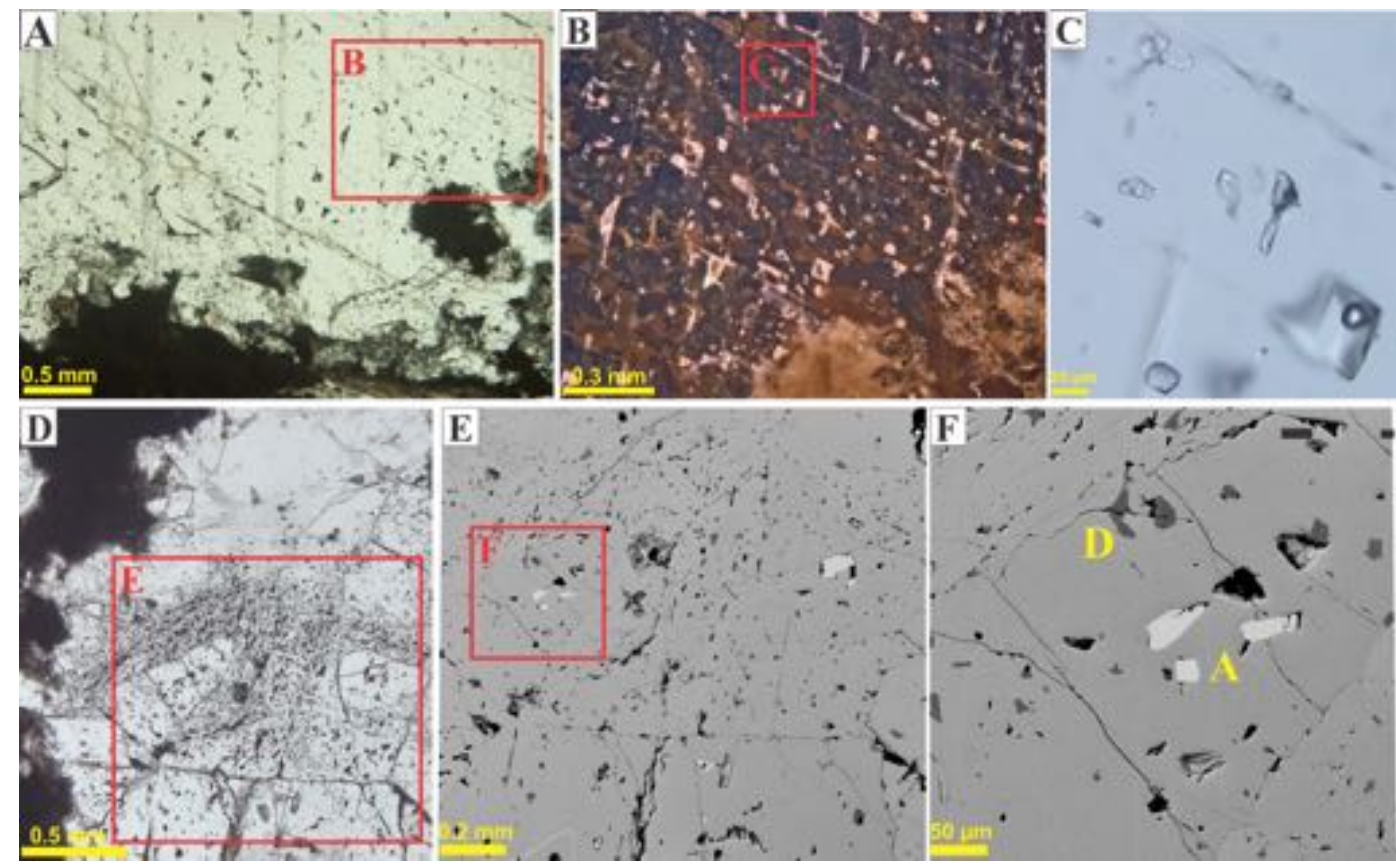


Figure 5. Petrography of fluid inclusions in nodular calcite. (A) Photomicrograph (PPL) of the margin of a large calcite nodule showing relatively abundant aqueous inclusions (dark spots). (B) CL image of (A), showing the markedly mottled characteristics and the abundant aqueous inclusions (bright spots). (C) Photomicrographs (PPL) of the biphase aqueous inclusions in the calcite in (B). (D) to (F): Photomicrograph (PPL; D) and BSE images (E, F) of calcite showing abundant corroded remnants of dolomite (D) and anhydrite (A). The rectangles in the photomicrographs and BSE images represent the next figure.

\subsection{Isotope geochemistry of carbonates and sulfates}

Calcite nodules with various amounts of anhydrite in the outer ramp facies have $\delta^{13} \mathrm{C}_{\mathrm{VPDB}}$ values ranging from -3.2 to $-0.1 \%$ (av. $-1.3 \%$ ) and $\delta^{18} \mathrm{O}_{\mathrm{VPDB}}$ values from -7.7 to $-4.0 \%$ (av. $-4.9 \%$; Fig. 6). Two Sr-isotope analyses of such calcite nodules have values of 0.707034 and 0.707057 . Bulk limestone samples display $\delta^{13} \mathrm{C}_{\mathrm{VPDB}}$ values from -3.0 to $+3.6 \%$ (av. $+1.9 \%$ ) and $\delta^{18} \mathrm{O}_{\mathrm{VPDB}}$ values from -6.6 to $-2.9 \%$ (av. $-4.9 \%$; Fig. 6 )

The $\delta^{34} \mathrm{~S}_{\mathrm{CDT}}$ values of anhydrite nodules, beds and cements in the supratidal and lagoon facies show similar values $(+17.4$ to $+20.2 \%$; av. $+18.7 \%)$. The $\delta^{34} \mathrm{~S}_{\mathrm{CDT}}$ values obtained for sulfate cements (anhydrite and celestine) in the outer ramp facies range from +23.1 to $+24.7 \%$ o (av. $+23.8 \%$ ). Sulfates in the supratidal/lagoon and outer ramp facies reveal

similar ${ }^{87} \mathrm{Sr} /{ }^{86} \mathrm{Sr}$ ratios between 0.70694 and 0.70698 (av. 0.70696) and between 0.70693 and 0.70701 (av. 0.70696), respectively. 


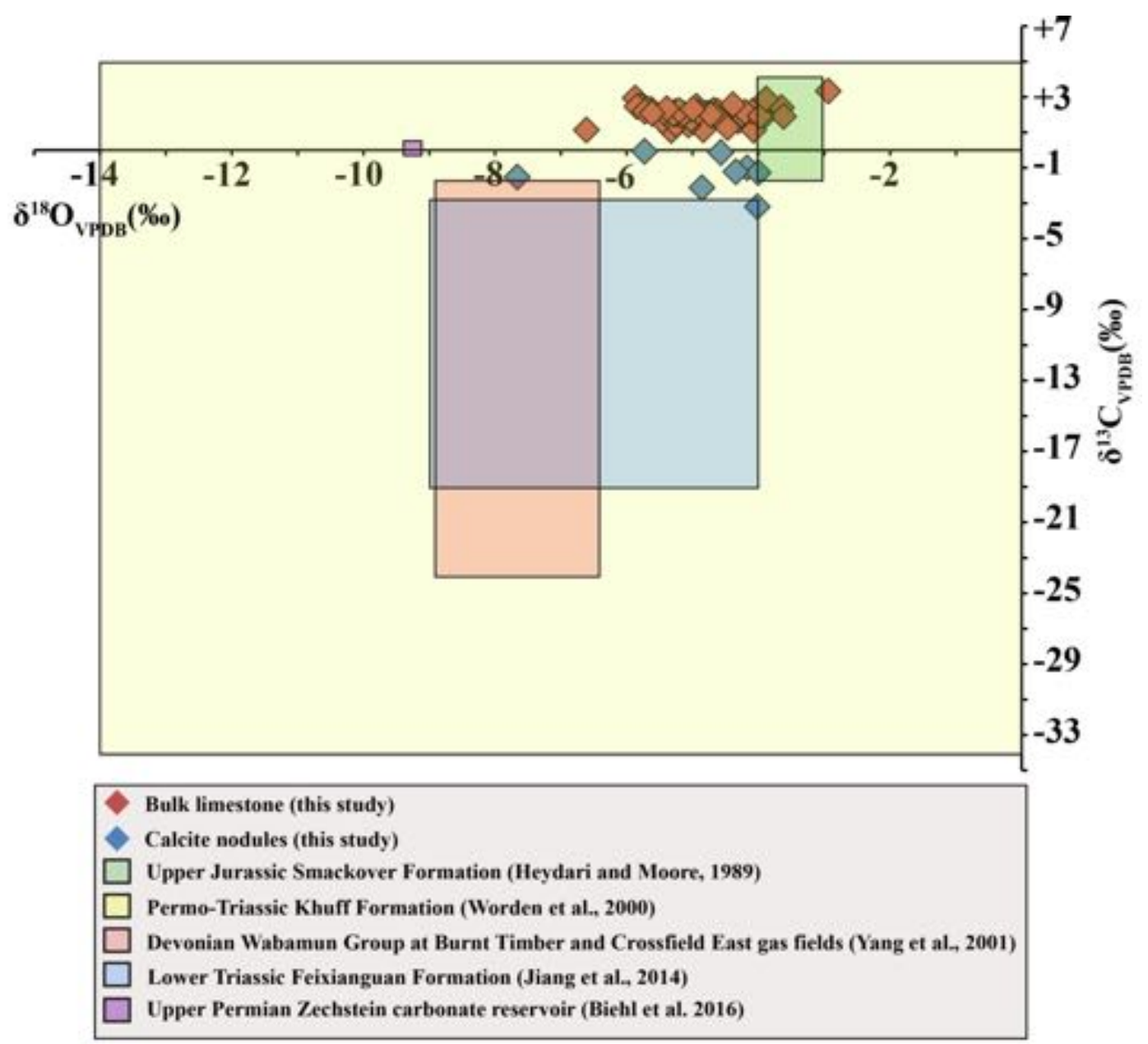

Figure 6. Carbon versus oxygen isotope cross plot showing that nodular calcite has lower $\delta^{13} \mathrm{C}_{\mathrm{VPDB}}$ values than the bulk limestone samples from the Arab Formation. Isotope compositions of calcite associated with TSR from other studies are included for purpose of comparison. The calcites in this study have slightly depleted $\delta^{13} \mathrm{C}_{\mathrm{VPDB}}$ values compared to bulk limestone samples.

\subsection{Fluid inclusion petrography, microthermometry and Raman spectroscopy}

Fluid inclusion (FI) petrography, microthermometry and Raman spectroscopy data were obtained from nodular and tabular calcite in the flanks, whereas FI in similar calcites from crest wells are rare and have thus not been analyzed. Observation of the FI under UVlight did not reveal any hydrocarbons containing aromatic compounds. Nodular and tabular 
calcite in the flank of the structure contain abundant aqueous and possibly primary FI. The calcite contains abundant clusters of aqueous biphase FI, particularly near the nodule margins (Fig. 5). The FI show negative crystal shapes near the margins (Fig. 5F), whereas more irregular shapes are observed towards the central parts of the calcite nodules (Fig 5D, E).

The overall $\mathrm{T}_{\mathrm{h}}$ range is $123^{\circ} \mathrm{C}$ to $>200^{\circ} \mathrm{C}(\mathrm{N}=170)$. However, most $\mathrm{T}_{\mathrm{h}}$ measurements fall between 135 and $157^{\circ} \mathrm{C}$ (Fig. 7A). In individual fluid inclusion assemblages (FIA), the $\mathrm{T}_{\mathrm{h}}$ measurements are mostly within a $10-15^{\circ} \mathrm{C}$ range, attesting that they did not experience significant post-entrapment modifications (e.g. neckingdown, stretching or leakage due to thermal reequilibration). Two FIA yielded relatively inconsistent $\mathrm{T}_{\mathrm{h}}\left(140\right.$ to $>200^{\circ} \mathrm{C}$, and 125 to $\left.165^{\circ} \mathrm{C}\right)$. However, in these FIA most inclusions homogenize in a narrow range $\left(140-155^{\circ} \mathrm{C}\right.$ and $137-151^{\circ} \mathrm{C}$, respectively). The higher temperature tails recorded in these two FIA (160$165^{\circ} \mathrm{C}$ and 163 to $>200^{\circ} \mathrm{C}$ ) are formed by FI showing highly variable liquid to vapor ratios. The high temperature limit $\left(200^{\circ} \mathrm{C}\right)$ is arbitrary, as some of the FI retained bubbles at this temperature. These bubbles show consistent volume changes during heating-cooling cycles, indicating that they have not resulted from leakage. The two FI that homogenize at temperatures below $130^{\circ} \mathrm{C}$ can belong to a different calcite generation or due to some error during measurements. The homogenization temperatures of the FI in the central parts of the calcite nodules are, in general lower, than near the margins. In aqueous and possibly secondary FI located along trails cutting through calcite nodules, the overall $\mathrm{T}_{\mathrm{h}}$ range is 138 $160^{\circ} \mathrm{C}(\mathrm{N}=75)$. However, in individual FIA the $\mathrm{T}_{\mathrm{h}}$ data is typically highly consistent. For instance, all the FI measured along a single trail $(\mathrm{N}=38)$ yielded $\mathrm{T}_{\mathrm{h}}$ ranging from 148 to $153^{\circ} \mathrm{C}$. The salinity of the aqueous $\mathrm{FI}$ in the calcite nodules ranges from 20.3 to $22.5 \mathrm{wt} \%$ $\mathrm{NaCl}$ eq. (Fig. 7B); the apparent eutectic temperatures range from around -50 to $-28^{\circ} \mathrm{C}$. 

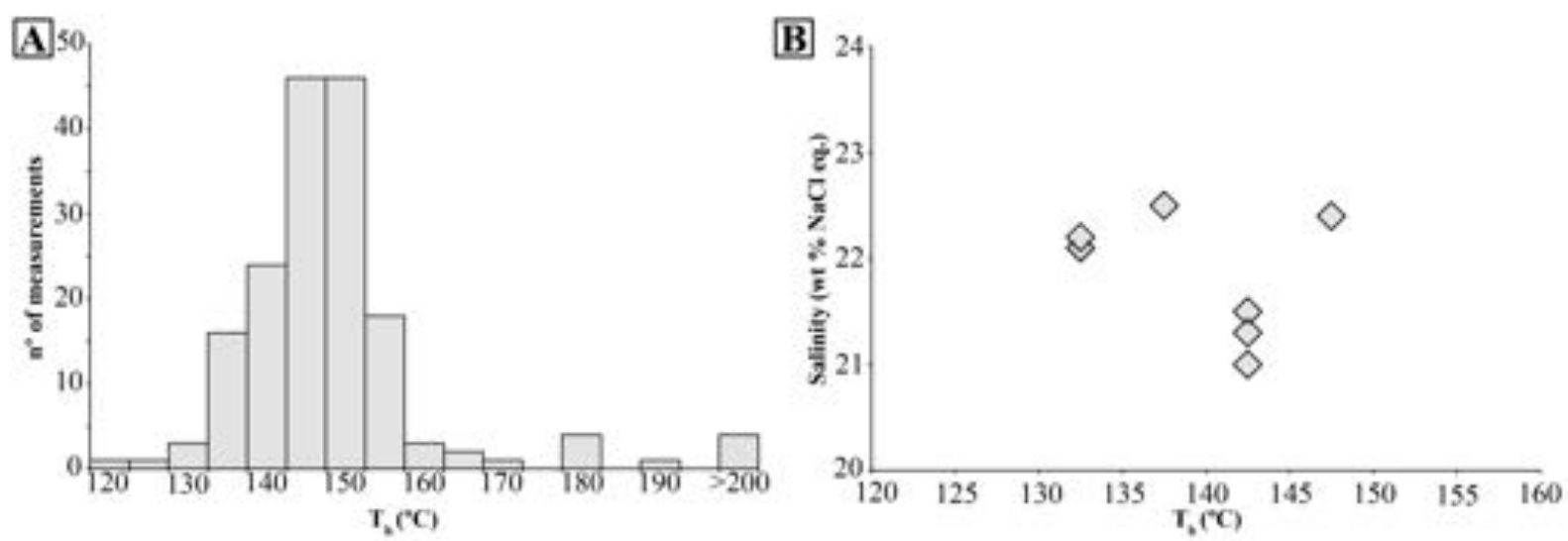

Figure 7. Homogenization temperatures $\left(T_{h}\right)$ and salinity data of aqueous and presumably primary fluid inclusions in nodular and tabular calcite obtained from the Arab Formation. (A) Histogram for all measured aqueous and presumably primary fluid inclusions. Most $T_{h}$ values range between 135 and $155^{\circ} \mathrm{C}$. (B) Cross-plot showing that there is no correlation between $\mathrm{T}_{\mathrm{h}}$ and salinity.

Raman spectroscopy of fluid inclusions in nodular calcite reveals the presence of methane and carbon dioxide in the gas phase. Hydrogen sulfide, methane and minor ethane and propane were detected in fluid inclusions in pore-filling calcite and in calcite replacing saddle dolomite, which are not associated with anhydrite.

\subsection{Gas composition}

Gas samples from well C (Fig. 1D) are composed mainly of methane, hydrogen sulfide and minor amounts of ethane and propane (Table 1). The $\mathrm{H}_{2} \mathrm{~S}$ content range between 19.55 and $23.74 \%$ and is slightly higher in the lower Arab D Member (av. 23.08\%) than in upper Arab D (av. 22.15\%) and Arab A-B-C members (av. 21.37\%). The dryness coefficient $\left(\mathrm{C}_{1} /\left(\mathrm{C}_{1}-\mathrm{C}_{3}\right)\right)$ of the gas, which indicates the relationship between the amounts of methane $\left(\mathrm{C}_{1}\right)$, ethane $\left(\mathrm{C}_{2}\right)$ and propane $\left(\mathrm{C}_{3}\right)$, varies between around 87 and 92 . The dryness coefficient 
is slightly higher in lower (av. 91.00\%) and upper (av. 91.09\%) Arab D than in Arab A-B-C (av. 88.77\%) members. The water (vapor) content in the crest of the anticline (i.e. gas zone) is around $1.5 \%$. 
Table 1. Gas composition and the dryness coefficient of gases in various depositional facies and formation members from well C.

\begin{tabular}{|c|c|c|c|c|c|c|}
\hline \multirow[t]{2}{*}{ Member } & \multirow[t]{2}{*}{ Depositional facies } & \multicolumn{4}{|c|}{ Gas chemical composition (\%) } & \multirow{2}{*}{$\begin{array}{l}\text { Dryness coefficient (\%) } \\
\mathrm{C}_{1} /\left(\mathrm{C}_{1}-\mathrm{C}_{3}\right)\end{array}$} \\
\hline & & $\mathrm{C}_{1}$ & $\mathrm{C}_{2}$ & $\mathrm{C}_{3}$ & $\mathrm{H}_{2} \mathrm{~S}$ & \\
\hline A-B-C & Supratidal/lagoon & 59.70 & 6.04 & 2.78 & 19.71 & 87.13 \\
\hline A-B-C & Supratidal/lagoon & 60.20 & 6.02 & 2.66 & 19.55 & 87.40 \\
\hline A-B-C & Supratidal/lagoon & 60.00 & 6.06 & 2.74 & 19.71 & 87.21 \\
\hline A-B-C & Supratidal/lagoon & 60.00 & 6.05 & 2.76 & 19.69 & 87.20 \\
\hline A-B-C & Supratidal/lagoon & 59.75 & 6.04 & 2.78 & 19.72 & 87.14 \\
\hline A-B-C & Supratidal/lagoon & 59.48 & 6.04 & 2.83 & 19.85 & 87.02 \\
\hline A-B-C & Supratidal/lagoon & 58.90 & 4.38 & 1.93 & 22.98 & 90.32 \\
\hline A-B-C & Supratidal/lagoon & 58.60 & 4.38 & 1.93 & 23.11 & 90.28 \\
\hline A-B-C & Supratidal/lagoon & 58.99 & 4.38 & 1.87 & 23.07 & 90.42 \\
\hline A-B-C & Supratidal/lagoon & 59.10 & 4.37 & 1.89 & 22.94 & 90.42 \\
\hline A-B-C & Supratidal/lagoon & 58.87 & 4.38 & 1.91 & 23.06 & 90.35 \\
\hline A-B-C & Supratidal/lagoon & 58.83 & 4.38 & 1.92 & 23.10 & 90.33 \\
\hline Upper D & Shoal & 60.37 & 4.23 & 1.67 & 22.11 & 91.10 \\
\hline Upper D & Shoal & 60.55 & 4.23 & 1.64 & 21.95 & 91.16 \\
\hline Upper D & Shoal & 61.24 & 4.23 & 1.59 & 21.34 & 91.32 \\
\hline Upper D & Shoal & 60.21 & 4.24 & 1.65 & 22.28 & 91.09 \\
\hline Upper D & Shoal & 59.66 & 4.25 & 1.69 & 22.61 & 90.95 \\
\hline Upper D & Shoal & 61.88 & 4.17 & 1.49 & 20.95 & 91.62 \\
\hline Upper D & Shoal & 59.11 & 4.27 & 1.76 & 23.06 & 90.74 \\
\hline Upper D & Shoal & 59.22 & 4.26 & 1.78 & 22.92 & 90.74 \\
\hline Lower D & Outer ramp & 61.38 & 4.07 & 1.45 & 21.31 & 91.75 \\
\hline Lower D & Outer ramp & 59.14 & 4.19 & 1.71 & 23.13 & 90.93 \\
\hline Lower D & Outer ramp & 60.57 & 4.15 & 1.51 & 22.13 & 91.45 \\
\hline Lower D & Outer ramp & 58.81 & 4.20 & 1.70 & 23.43 & 90.88 \\
\hline Lower D & Outer ramp & 58.27 & 4.20 & 1.74 & 23.66 & 90.75 \\
\hline Lower D & Outer ramp & 58.35 & 4.20 & 1.74 & 23.59 & 90.76 \\
\hline Lower D & Outer ramp & 58.11 & 4.20 & 1.75 & 23.65 & 90.71 \\
\hline Lower D & Outer ramp & 58.11 & 4.21 & 1.70 & 23.74 & 90.77 \\
\hline
\end{tabular}


Porosity and permeability values of carbonates in the various depositional facies and corresponding lithologies and limestone textures in the crest and flank are shown in Table 2. Porosity and permeability are higher in carbonates from the crest than from the flank. The highest porosity and permeability values in the Arab A-B-C members (i.e. supratidal and lagoon facies) are encountered in dolostones that are poor in anhydrite cement. The highest porosity and permeability values in upper D (i.e. shoal facies) are in grainstones with high intergranular macro- and microporosity. The lower D (i.e. outer ramp facies) is characterized by overall low porosity and permeability values. A few samples with unusually high permeability and low porosity values are attributed to microfractures. 
Table 2. Porosity and permeability values of samples from the various depositional facies and formation members in the crest and flank of the anticline.

Depositionalfacies Lithology $\quad$ Porosity (\%) $\quad$ Average Permeability (mD) Average

\section{Crest}

\begin{tabular}{|c|c|c|c|c|c|c|}
\hline Arab A-B-C & Supratidal & Anhydrite/dolomicrite & $0.1-6.6$ & 0.9 & $0-11.6$ & 0.5 \\
\hline Arab A-B-C & Lagoon & Dolostones & $0.2-28.8$ & 13.5 & $0-43.9$ & 5.1 \\
\hline Arab A-B-C & Lagoon & Lime mud-/wackestone & $0.2-16.3$ & 2.7 & $0-19.1$ & 0.8 \\
\hline Upper D & Shoal & Lime pack-/grainstone & $1.8-28.8$ & 18.5 & $0-254.0$ & 3.9 \\
\hline Lower D & Outer ramp & $\begin{array}{l}\text { Lime mud-/wacke- } \\
\text { /floatstone }\end{array}$ & $1.1-19.1$ & 6.7 & $0-82.0$ & 1.0 \\
\hline \multicolumn{7}{|l|}{ Flank } \\
\hline Arab A-B-C & Supratidal & No data & No data & No data & No data & No data \\
\hline Arab A-B-C & Lagoon & Lime mud-/wackestone & $0-1.3$ & 0.6 & $0-40.1$ & 1.9 \\
\hline Upper D & Shoal & Lime pack-/grainstone & $0.4-3.2$ & 1.7 & $0-1.3$ & 0.2 \\
\hline Lower D & Outer ramp & Lime mud-/wacke- & $0.2-12.7$ & 1.3 & $0-54.1$ & 2.2 \\
\hline
\end{tabular}

/floatstone 


\section{Discussion}

Integrating the results from petrography, stable isotopes and fluid inclusion microthermometry and Raman spectroscopy into the burial-thermal history allowed us to constrain the reasons behind the limited evidence of TSR, origin of abundant $\mathrm{H}_{2} \mathrm{~S}$ and relative timing of sour gas emplacement in the studied Upper Jurassic Arab Formation reservoir.

\subsection{Evidence and conditions of thermochemical sulfate reduction}

Hydrogen sulfide $\left(\mathrm{H}_{2} \mathrm{~S}\right)$ is abundant in Arab Formation gas reservoirs in Abu Dhabi, particularly in the onshore fields, which are buried deeper than in offshore fields (Grötsch et al., 2003). $\mathrm{H}_{2} \mathrm{~S}$ in carbonate reservoirs can be produced by both bacterial sulfate reduction (BSR) and thermochemical sulfate reduction (TSR; Machel, 2001). The following lines of evidence suggest that limited TSR, i.e. the reaction between hydrocarbons (methane, ethane and propane) and anhydrite, can account for the formation of limited amounts of $\mathrm{H}_{2} \mathrm{~S}$ and calcite in the studied reservoir: (i) the presence of petrographic evidence for replacement of anhydrite and minor celestine by calcite (Fig. 3, 4). This evidence is indicated by calcite nodules and crystals that contain tiny remnants of anhydrite and resemble anhydrite precursors (e.g. nodules and tabular crystals). (ii) The lower $\delta^{13} \mathrm{C}_{\mathrm{VPDB}}$ values $(-3.2$ to $-0.1 \%$ ) of calcite that has replaced anhydrite compared to those of the host limestones (av. $+1.9 \%$ ), which have $\delta^{13} \mathrm{C}_{\mathrm{VPDB}}$ values of calcites precipitated in equilibrium with Late Jurassic seawater $\left(\delta^{13} \mathrm{C}_{\mathrm{VPDB}}=-0.1\right.$ to $+2.5 \%$; Veizer et al., 1999). Wide ranges of $\delta^{13} \mathrm{C}_{\mathrm{VPDB}}$ values have been reported in the literature for calcite derived from TSR. While most values for such calcite are far more negative than those obtained in this study (Fig. 6; Worden et al., 2000; Yang et al., 2001; Jiang et al., 2014), denoting derivation of dissolved carbon from the oxidation of 
hydrocarbons, Heydari and Moore (1989) have reported similar to considerably higher $\delta^{13} \mathrm{C}_{\mathrm{VPDB}}$ values $(-1.7 \%$ o to $+4.2 \%$ ) in the Jurassic Smackover Formation (USA). These authors suggested that such high values were because the $\delta^{13} \mathrm{C}$ was mainly derived from host rock. The marginally depleted $\delta^{13} \mathrm{C}_{\mathrm{VPDB}}$ values of such calcite corroborate the limited TSR in the studied Arab Formation, i.e. most dissolved carbon was derived from the host limestone and not from the oxidization of methane. (ii) The relatively high precipitation temperatures inferred form FI homogenization for the calcite that has replaced anhydrite $\left(\sim 130-160^{\circ} \mathrm{C}\right)$ are around or above the minimum temperatures required for TSR (i.e. $>110$ to $140^{\circ} \mathrm{C}$; Worden et al., 1995; Machel, 1998; Worden et al., 2004). Knowing that the vapor phase in the analyzed fluid inclusions in this study contains some methane (as detected by Raman spectroscopy), the pressure corrections should be minimal (Goldstein and Reynolds, 1994), i.e. the $\mathrm{T}_{\mathrm{h}}$ values are probably very close to true entrapment temperatures. (iv) The low dryness coefficient $\left(\mathrm{C}_{1} /\left(\mathrm{C}_{1}-\mathrm{C}_{3}\right)=\sim 87-92\right.$; Table 1$)$ of gas samples obtained from the various depositional facies is consistent with relatively limited TSR in the reservoir because ethane $\left(\mathrm{C}_{2}\right)$ and propane $\left(\mathrm{C}_{3}\right)$ are preferentially removed during TSR (Krouse et al., 1988). (v) The presence of pyrite and sphalerite in the studied formation (Morad et al., 2018), as well as $\mathrm{CO}_{2}$ and $\mathrm{H}_{2} \mathrm{~S}$ detected by Raman spectroscopy in fluid inclusions, which are all typical byproducts of TSR (e.g. Machel, 2001).

\subsection{Temperature, fluid composition and timing of TSR}

The minimum temperature required for TSR is controversial and has been suggested to vary from around 110 to $140^{\circ} \mathrm{C}$ (Krouse et al., 1988; Heydari and Moore, 1989; Machel, 1998; Worden et al., 2000, Yang et al., 2001; Worden et al., 2004). The fluid inclusion microthermometry of calcite that has replaced anhydrite in the studied reservoir suggests that 
TSR occurred mostly between $135^{\circ} \mathrm{C}$ and $155^{\circ} \mathrm{C}$. These temperatures are comparable to bottom hole temperatures in the crest and flanks, respectively. The homogenization temperatures $\left(T_{h}\right)$ coupled with the modeled burial-tectonic history (Al Darmaki et al., 2014; Fig. 8) suggest that TSR commenced at around $2.7 \mathrm{~km}$ depth around 35-50 Ma ago (Early to Late Eocene). This interpretation is made derived assuming that TSR starts at around $130^{\circ} \mathrm{C}$ and a mean geothermal gradient of $38^{\circ} \mathrm{C} / \mathrm{km}$ (Fig. 8, 9).

By using the main $\mathrm{T}_{\mathrm{h}}$ range $\left(135-155^{\circ} \mathrm{C}\right)$, the $\delta^{18} \mathrm{O}_{\mathrm{VPDB}}$ values $(-7.7$ to $-4.0 \%$ of TSR calcite and the calcite-water oxygen isotope fractionation equation of Friedman and O'Neil (1977), a $\delta^{18} \mathrm{O}_{\text {SMOW }}$ signature of +9.2 to $+14.5 \%$ o can be deduced for the water from

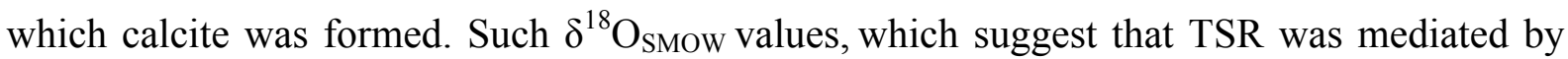
geochemically evolved basinal brines (cf. Zeeh et al., 1995; Calvo et al., 2011; Dickson and Kenter, 2014), have been reported for TSR calcites elsewhere by Yang et al. $(2001 ;+7.8$ to $+11.7 \%$ ) and Machel and Buschkuehle $(2008 ;+4$ to $+13 \%)$. Moreover, the salinity data $(20.3$ and $22.5 \mathrm{wt} \% \mathrm{NaCl}$ eq.) obtained from fluid inclusion microthermometry of calcite are typical for basinal brines. Based on the apparent eutectic temperatures $\left(-50\right.$ to $\left.-28^{\circ} \mathrm{C}\right)$ of the fluid inclusions of TSR calcite, the fluids can be characterized as $\mathrm{NaCl}-\mathrm{CaCl}_{2}-\mathrm{MgCl}_{2}$ dominated (cf. Goldstein and Reynolds, 1994).

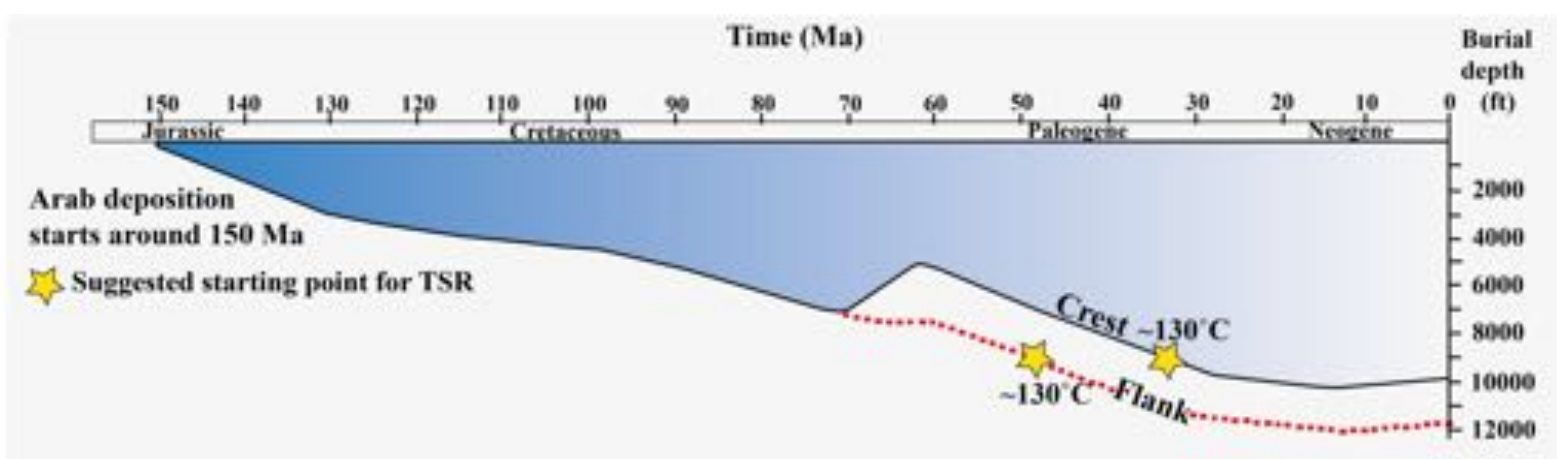

Figure 8. Burial history curve of the Arab Formation for the studied crest and flank wells spanning from deposition to present time (modified from Al Darmaki et al., 2014). A small 
uplift and development of anticline of the field during Late Cretaceous were associated with the obduction of Oman ophiolites. TSR is suggested to start at around $130^{\circ} \mathrm{C}$, meaning that TSR starts earlier on the flanks and then on the crest.

\subsection{Origin of hydrogen sulfide - evidence of limited TSR}

The presence of up to 38 vol. $\% \mathrm{H}_{2} \mathrm{~S}$ in the studied field (Nederlof et al., 2016) suggests derivation by extensive TSR. However, the unexpected presence of only limited amounts of calcitized anhydrite indicates that TSR is relatively limited in the studied sour gas reservoir. Hence, the high amounts of $\mathrm{H}_{2} \mathrm{~S}$ have presumably been mostly derived from elsewhere in the basin. Based on ${ }^{34} \mathrm{~S}_{\mathrm{CDT}}$ values of $\mathrm{H}_{2} \mathrm{~S}$ in the lower parts if the formation (i.e. lower Arab D), Nederlof et al. (2016) suggested that the $\mathrm{H}_{2} \mathrm{~S}$ was derived from TSR in the underlying early Upper Jurassic Hanifa Formation, whereas $\mathrm{H}_{2} \mathrm{~S}$ in the upper parts of the formation (i.e. Arab A, B, C) was formed in-situ. These authors have based their interpretation on the similar ${ }^{34} \mathrm{~S}_{\mathrm{CDT}}$ values of the anhydrite and $\mathrm{H}_{2} \mathrm{~S}$, i.e. assuming there will be only minor or no sulfur isotopic fractionation during TSR (Yang et al., 2001). However, the ${ }^{34} \mathrm{~S}_{\mathrm{CDT}}$ values obtained in the present study for anhydrites in the Arab $\mathrm{D}$, which were not analyzed by Nederlof et al. (2016), are similar to the ${ }^{34} \mathrm{~S}_{\mathrm{CDT}}$ values of the $\mathrm{H}_{2} \mathrm{~S}$ in the Arab D (Nederlof et al., 2016). Consequently, at least some of the $\mathrm{H}_{2} \mathrm{~S}$ in the Arab D was also derived from in-situ TSR. Moreover, lower amounts of $\mathrm{H}_{2} \mathrm{~S}$ in the upper parts of the formation compared to the lower parts (Nederlof et al., 2016) supports our interpretation that TSR was relatively more extensive in the lower parts (Fig. 3). Nevertheless, the limited amounts of sulfates in the lower parts of the formation indicate that all the bulk of the abundant $\mathrm{H}_{2} \mathrm{~S}$ could not be derived from TSR within the Arab Formation. Hence, migration of $\mathrm{H}_{2} \mathrm{~S}$ from underlying formations (Grötsch et al., 2003) is a more plausible explanation for the high 
amounts of $\mathrm{H}_{2} \mathrm{~S}$ in the Arab Formation. The underlying Permo-Triassic Khuff Formation (Worden et al., 2000) and/or early Upper Jurassic Hanifa (Nederlof et al., 2016) are possible external sources of the $\mathrm{H}_{2} \mathrm{~S}$.

The reasons behind the limited extent of TSR despite the presence of ideal conditions in the studied succession, i.e. sufficiently high temperatures and presence of abundant sulfates, are not fully understood. One reason could be gas emplacement during shallow burial before temperatures increased high enough to ensure extensive TSR. Numerous studies have concluded that high hydrocarbon saturation in carbonate reservoirs might retard or even stop diagenesis including extensive TSR (Machel et al., 1995; Machel, 1998) because minerals (in this case anhydrite) have nil solubility in gas (Fezel and Schatzinger, 1985; Heasley et al., 2000; Cox et al., 2010; Paganoni et al., 2016; Morad et al., 2018). Thus, while TSR was presumably retarded in the crest (i.e. gas zone) due to gas emplacement, it continued during gas migration through the water-saturated flanks. This scenario is depicted in figure 9. Migration of hydrocarbons in the flank is supported by the presence of methane, ethane and propane in fluid inclusions in calcite cements. Moreover, the somewhat more extensive TSR in the lower than in the upper parts of the studied formation might be because: (i) the anhydrite nodules in the upper parts contain finer crystals than those in the lower parts. Worden et al. (2000) noted that finer crystals experience more TSR than coarser crystals in the Permo-Triassic Khuff Formation. However, we did not observe any clear correlation between crystal size and TSR in this study; or (ii) gas emplacement is expected to start in the upper parts of the succession and continue downwards (Fig. 9). This is the more plausible scenario because gradual gas emplacement would lead to earlier retardation of TSR in the upper parts compared to the lower parts of the formation. Nevertheless, anhydrite has a greater surface affinity for water than non-polar alkanes (e.g. methane, ethane, propane), which suggests that alkane-anhydrite systems are always water-wet rather than gas-wet, even 
after gas emplacement (Worden et al., 2000). Hence, even if the overall diagenesis was retarded substantially in the crest after gas emplacement, anhydrite dissolution could have continued in the presence of irreducible water. However, the low total water content $(1.5 \%)$ in the reservoir suggests that the anhydrite is presumably gas wet (Fig. 9).

Figure 9. Schematic conceptual model of the extent of TSR in the Arab Formation across the anticline of the field. (A) Formation of the anticline and gas migration occurred in Late Cretaceous during the obduction of the Oman ophiolites. TSR started in the flanks at around $130^{\circ} \mathrm{C}$ in Early Eocene during gas migration when the reservoir temperatures were too low to cause extensive TSR in the crest. (B) TSR continued in the flanks and commenced in the lower parts (i.e. outer ramp) of the crest but not in the upper parts (i.e. supratidal and lagoon) because of early gas emplacement in Early to Late Eocene. (C) TSR continued in the watersaturated flanks, whereas stopped or slowed down significantly in the crest because of gas emplacement during the Late Eocene.

\subsection{Interplay between TSR and porosity and permeability}

It has been argued in the literature that there is interplay between porosity and permeability of the host carbonate reservoir and the rates of TSR. High porosity and permeability, which implies increase in rates of fluid flux and water/rock ratios, could increase the rates of anhydrite dissolution and migration of hydrocarbons, and hence the rate of TSR (Worden et al., 2000; Machel, 2001). Despite this, we found that the lower porosity and permeability in the mud dominated carbonates of outer ramp facies exhibit evidence of relatively more extensive TSR compared to the higher porosity and permeability dolostones in 
the lagoon facies in the crest. Therefore, the rates of anhydrite dissolution and gas migration to the reaction site are presumably not controlling the extent of TSR in the Arab Formation. In the flank, however, the overall significantly lower porosity and permeability, which has been suggested to be because calcite cementation associated with stylolitization continued after gas emplacement in the crest (Morad et al., 2018), could hinder gas migration to the upper parts of the formation and, thus, prevent TSR. TSR might be common in the outer ramp facies in the flank because these rocks contain stylolites, which act as conduits for flux of gas and other fluids. This postulation is supported by: (i) the common presence of saddle dolomite and fluorite cements along stylolites and related fractures (Morad et al., 2018), which are more frequent and better developed in the flanks than in the crest. It has been suggested in the literature that stylolites and fractures act as conduits for flux of hot basinal fluids (Davies and Smith, 2006; Mansurbeg et al., 2016; Paganoni et al., 2016). (ii) The presence of $\mathrm{CH}_{4}$ bearing fluid inclusions in these cements, indicating that gases required for TSR was present. Such types of cements and fluid inclusions are common in the lower parts while absent in the upper parts of the formation, which witness difference in rates of fluid flow.

$\mathrm{H}_{2} \mathrm{~S}$ is an aggressive gas that can cause mineral dissolution. Accordingly, TSR has been suggested to improve reservoir quality (e.g. Hill, 1995; Ma et al., 2007; Morad et al., 2012; Jiang et al., 2018). However, we did not observe any evidence indicating that TSR affected the reservoir quality in the studied succession, which is in agreement with other studies (e.g. Machel et al., 1995; Heydari, 1997; Machel, 2001; Hao et al., 2015). A possible scenario is that the methane, ethane and propane were emplaced in the reservoir before $\mathrm{H}_{2} \mathrm{~S}$, and hence inhibited any further diagenesis including dissolution. Instead, the better reservoir properties of the limestones on the crest compared to those on the flanks was attributed by Morad et al. (2018) to preservation of porosity and permeability due to gas emplacement rather than creation by mineral dissolution. Morad et al. (2018) attributed the destruction of 
reservoir quality in the flanks to continuous chemical compaction and cementation.

\section{Conclusions}

The main findings of this integrated petrographic, isotope, fluid inclusion microthermometry and Raman spectroscopy study of thermochemical sulfate reduction (TSR) in the Jurassic hot, anhydrite-rich carbonate reservoirs include:

- Despite the presence of abundant $\mathrm{H}_{2} \mathrm{~S}$ in the sour gas reservoir, there is limited evidence of TSR, which is manifested by rare calcitization of anhydrite. Carbon isotope composition of calcite replacing anhydrite $\left(\delta^{13} \mathrm{C}_{\mathrm{VPDB}}=-3.2\right.$ to $-0.1 \%$ o indicates that dissolved carbon was derived mainly from the host Jurassic carbonates and only partly from oxidation of hydrocarbons.

- The limited TSR despite the high temperatures reached by the reservoir and presence of abundant anhydrite deposits in the crest (i.e. gas zone) is attributed to emplacement of gas before burial of the reservoir to depths that promote TSR. In other words, early gas emplacement retarded diagenesis including TSR.

- Consequently, most of the abundant $\mathrm{H}_{2} \mathrm{~S}$ present in the sour gas reservoir has migrated from underlying anhydrite-rich early Upper Jurassic and/or Permo-Triassic carbonate deposits that are undergoing TSR.

- Fluid inclusion microthermometry of calcitized anhydrite indicates that limited TSR occurred at temperatures between $140^{\circ} \mathrm{C}$ and $155^{\circ} \mathrm{C}$ in the presence of geochemically evolved $\left(\delta^{18} \mathrm{O}_{\text {SMOW }}=+9.2\right.$ to $\left.+14.5 \%\right)$, highly saline $(20.3$ and $22.5 \mathrm{wt} \% \mathrm{NaCl}$ eq. $)$, $\mathrm{NaCl}-\mathrm{CaCl}_{2}-\mathrm{MgCl}_{2}$ dominated brines.

- There was no impact of TSR on mineral dissolution and thus not on reservoir quality 
presumably because gas (methane ethane and propane) migration and emplacement in the reservoir occurred before the migration of $\mathrm{H}_{2} \mathrm{~S}$. Hence, gas emplacement inhibited any further diagenesis including any possible dissolution associated with TSR.

- The more extensive TSR in the lower than upper parts of the crest is attributed to gradual gas saturation of the reservoir starting in the upper and then in the lower part of the anticline.

- This study demonstrates that the presence of abundant $\mathrm{H}_{2} \mathrm{~S}$ in anhydrite-rich, hot carbonate sour gas reservoir does not automatically imply extensive TSR in-situ. Derivation of $\mathrm{H}_{2} \mathrm{~S}$ from other parts of the basin where abundant $\mathrm{H}_{2} \mathrm{~S}$ is formed by TSR should have important implication for origin and timing of fluid (including hydrocarbons) migration and hence for successful exploration strategies in sedimentary basins.

\section{Acknowledgements}

We are grateful to the Petroleum Institute for funding this project (PIRC project number LTR14012) and ADNOC Sour Gas, ADNOC and Oxy for giving us access to samples and data as well as for permission to publish this paper. We would also like to thank Ihsan Al-Aasm for his generous help with the isotope analyses.

\section{References}

Al Darmaki, F., Mattner, J., Bouzida, Y., Cavailhes, T., Burreson, M., Lawrence, D.A., Lucas, N. 2014. Identification, Upscaling and Modeling Strategy for Multi-Scale Fracture Networks 
in Variable Lithology Reservoirs. In EAGE Borehole Geology Workshop, 13-15 October, Dubai, UAE.

Alsharhan, A.S., 1989. Petroleum geology of the United Arab Emirates. Journal of Petroleum Geology, 123, 253-288.

Alsharhan, A.S., Scott, R.W., 2000. Hydrocarbon potential of Mesozoic carbonate platformbasin systems, UAE. Middle East models of Jurassic/Cretaceous Carbonate Systems. SEPM Special Publication 69, 335-358.

Alsharhan, A.S., Whittle, G.L., 1995. Carbonate-evaporite sequences of the Late Jurassic, southern and southwestern Arabian Gulf. AAPG Bulletin, 79, 1608-1630.

Ayoub, M.R., En Nadi, I.M., 2000. Stratigraphic Framework and Reservoir Development of the Upper Jurassic in Abu Dhabi Onshore Area, UAE. SEPM Special Publication 69, 229-248

Bildstein, O., Worden, R.H., Brosse, E., 2001. Assessment of anhydrite dissolution as the ratelimiting step during thermochemical sulfate reduction. Chemical Geology, 176, 173-189.

Bodnar, R.J., 1993. Revised equation and table for determining the freezing point depression of $\mathrm{H}_{2} \mathrm{O}-\mathrm{NaCl}$ solutions. Geochimica et Cosmochimica Acta, 57, 683-684.

Calvo, R., Ayalon, A., Bein, A., Sass, E., 2011. Chemical and isotopic composition of diagenetic carbonate cements and its relation to hydrocarbon accumulation in the Heletz-Kokhav oil field (Israel). Journal of Geochemical Exploration, 108, 88-98.

Cox, P.A., Wood, R.A., Dickson, J.A.D., Al Rougha, H.B., Shebl, H., Corbett, P.W.M., 2010. Dynamics of cementation in response to oil charge: evidence from a Cretaceous carbonate field, UAE. Sedimentary Geology, 228, 246-254.

Davies, G.R., Smith Jr, L.B., 2006. Structurally controlled hydrothermal dolomite reservoir facies: An overview. AAPG Bulletin, 90, 1641-1690. 
Dickson, J.A.D., Kenter, J.A.M., 2014. Diagenetic evolution of selected parasequences across a carbonate platform: Late Paleozoic, Tengiz Reservoir, Kazakhstan. Journal of Sedimentary Research, 84, 664-693.

Feazel, C.T., Schatzinger, R.A., 1985. Prevention of carbonate cementation in petroleum reservoirs. In: Schneiderman, N., Harris, P.M. (Eds.), Carbonate Cements. SEPM Special Publication, 36, 97-106.

Friedman, I., O'Neil, J.R., 1977. Compilation of stable isotope fractionation factors of geochemical interest. Sixth ed. Data of Geochemistry 440, USGPO, pp. KK1-KK12.

Goldstein, R.H., Reynolds, T.J., 1994. Systematics of fluid inclusions in diagenetic minerals: SEPM short course 31. Society for Sedimentary Geology (199 pp).

Grötsch, J., Suwaina, O., Ajlani, G., Taher, A., Khassawneh, R., Lokier, S., Coy, G., van der Weerd, E., Masalmeh, S., van Dorp, J., 2003. The Arab Formation in central Abu Dhabi: 3-D reservoir architecture and static and dynamic modeling. GeoArabia, 8, 47-86.

Hao, F., Zhang, X., Wang, C., Li, P., Guo, T., Zou, H., Zhu, Y., Liu, J., Cai, Z., 2015. The fate of $\mathrm{CO} 2$ derived from thermochemical sulfate reduction (TSR) and effect of TSR on carbonate porosity and permeability, Sichuan Basin, China. Earth-Science Reviews, 141, 154-177.

Heasley, E.C., Worden, R.H., Hendry, J.P., 2000. Cement distribution in a carbonate reservoir: recognition of a palaeo oil-water contact and its relationship to reservoir quality in the Humbly Grove field, onshore, UK. Marine and Petroleum Geology, 17, 639-654.

Heydari, E., 1997. The role of burial diagenesis in hydrocarbon destruction and $\mathrm{H}_{2} \mathrm{~S}$ accumulation, Upper Jurassic Smackover Formation, Black Creek Field, Mississippi. AAPG Bulletin, 81, 26-45.

Heydari, E., Moore, C.H., 1989. Burial diagenesis and thermochemical sulfate reduction, Smackover Formation, southeastern Mississippi salt basin. Geology, 17, 1080-1084. 
Hill, C.A., 1995. $\mathrm{H}_{2}$ S-related porosity and sulfuric acid oil-field karst. In D.A. Budd, A.H. Saller, and P.M. Harris eds., Unconformities in carbonate strata-their recognition and the significance of associated porosity: AAPG Memoir 61, 301-306

Jiang, L., Worden, R.H., Cai, C.F., 2014. Thermochemical sulfate reduction and fluid evolution of the Lower Triassic Feixianguan Formation sour gas reservoirs, northeast Sichuan Basin, China. AAPG Bulletin, 98, 947-973.

Jiang, L., Worden, R.H., Yang, C., 2018. Thermochemical sulphate reduction can improve carbonate petroleum reservoir quality. Geochimica et Cosmochimica Acta, 223, 127-140.

Kampschulte, A., Strauss, H., 2004. The sulfur isotopic evolution of Phanerozoic seawater based on the analysis of structurally substituted sulfate in carbonates. Chemical Geology, 204, $255-286$.

Koyi, H., Sirat, M., Morad, D., 2015. Analogue Modelling of Shah Structure in Abu Dhabi; Mode and Structural Evolution. In Abu Dhabi International Petroleum Exhibition and Conference, 9-12 November, Abu Dhabi, UAE. SPE Paper 177446-MS, pp 1-8.

Krouse, H.R., Viau, C.A., Eliuk, L.S., Ueda, A., Halas, S., 1988. Chemical and isotopic evidence of thermochemical sulphate reduction by light hydrocarbon gases in deep carbonate reservoirs. Nature, 333, 415-419.

Lawrence, D.A., Hollis, C., Green, D., de Perière, M.D., Al Darmaki, F., Bouzida, Y., 2015. Palaeogeographic Reconstruction of a Tide-Dominated Oolite Shoal Complex in the Lower Arab Formation, Onshore UAE. In Abu Dhabi International Petroleum Exhibition and Conference, 9-12 November, Abu Dhabi, UAE, SPE paper 172769-MS, 1-21.

Ma, Y., Guo, X., Guo, T., Huang, R., Cai, X., Li, G., 2007. The Puguang gas field: New giant discovery in the mature Sichuan Basin, southwest China. AAPG Bulletin, 91, 627-643. 
Machel, H.G., 1998. Comment on" The effects of thermochemical sulfate reaction upon formation water salinity and oxygen isotopes in carbonate reservoirs" by RH Worden, PC Smalley, and NH Oxtoby. Geochimica et Cosmochimica Acta, 62, 337-342.

Machel, H.G., 2001. Bacterial and thermochemical sulfate reduction in diagenetic settings—old and new insights. Sedimentary Geology, 140, 143-175.

Machel, H.G., 2013. Secondary anhydrites in deeply buried Devonian carbonates of the Alberta Basin, Canada. Carbonates and Evaporites, 28, 267-280.

Machel, H.G., Buschkuehle, B. E., 2008. Diagenesis of the Devonian Southesk-Cairn Carbonate Complex, Alberta, Canada: marine cementation, burial dolomitization, thermochemical sulfate reduction, anhydritization, and squeegee fluid flow. Journal of Sedimentary Research, 78, 366-389.

Machel, H.G., Krouse, H. R., Sassen, R., 1995. Products and distinguishing criteria of bacterial and thermochemical sulfate reduction. Applied geochemistry, 10, 373-389.

Mansurbeg, H., Morad, D., Othman, R., Morad, S., Ceriani, A., Al-Aasm, I., Kolo, K., Spirov, P., Proust, J.N., Preat, A., Koyi, H., 2016. Hydrothermal dolomitization of the Bekhme formation (Upper Cretaceous), Zagros Basin, Kurdistan Region of Iraq: Record of oil migration and degradation. Sedimentary Geology, 341, 147-162.

Marchionda, E., Deschamps, R., Cobianchi, M., Nader, F.H., Di Giulio, A., Morad, D.J., Al Darmaki, F., Ceriani, A., 2018. Field-scale depositional evolution of the Upper Jurassic Arab Formation (onshore Abu Dhabi, UAE). Marine and Petroleum Geology, 89, 350-369.

Morad, S., Al-Aasm, I.S., Nader, F.H., Ceriani, A., Gasparrini, M., Mansurbeg, H., 2012. Impact of diagenesis on the spatial and temporal distribution of reservoir quality in the Jurassic Arab D and C members, offshore Abu Dhabi oilfield, United Arab Emirates. GeoArabia, 17, 1756. 
Morad, D., Nader, F. H., Gasparrini, M., Morad, S., Rossi, C., Marchionda, E., Al Darmaki, F., Martines, M., Hellevang, H., 2018. Comparison of the diagenetic and reservoir quality evolution between the anticline crest and flank of an Upper Jurassic carbonate gas reservoir, Abu Dhabi, United Arab Emirates. Sedimentary Geology, 367, 96-113.

Nader, F. H., Boever, E., Gasparrini, M., Liberati, M., Dumont, C., Ceriani, A., Morad, S., Lerat, O., Doligez, B., 2013. Quantification of diagenesis impact on the reservoir properties of the Jurassic Arab D and C members (Offshore, UAE). Geofluids, 13, 204-220.

Nederlof, P., Kaczorowski, N., Lawrence, D., 2016. The Origin of $\mathrm{H}_{2} \mathrm{~S}$ in the Arab Reservoirs in Abu Dhabi. In Abu Dhabi International Petroleum Exhibition and Conference, 7-10 November, Abu Dhabi, UAE, SPE paper 183336-MS, 1-10.

Paganoni, M., Al Harthi, A., Morad, D., Morad, S., Ceriani, A., Mansurbeg, H., Al Suwaidi, A., Al-Aasm, I.S., Ehrenberg, S.N., Sirat, M., 2016. Impact of stylolitization on diagenesis of a Lower Cretaceous carbonate reservoir from a giant oilfield, Abu Dhabi, United Arab Emirates. Sedimentary Geology, 335, 70-92.

Roduit, N., 2005. Two complementary efficient methods to quantify porosity types in digital images of thin sections with the software JmicroVision. In 24th IAS Meeting, Oman, abstracts, 142 .

Roedder, E., Kopp, O.C., 1975. A check on the validity of the pressure correction in inclusion geothermometry, using hydrothermally grown quartz. Fortschritte der Mineralogie, 52, 431446.

Rossi, C., Goldstein R.H., Marfil, R., Salas, R., Benito, M.A., Permanyer, A., De la Peña, J.A., Caja, M.A., 2001. Diagenetic and Oil Migration History of the Kimmeridgian Ascla Formation, Maestrat Basin, Spain: Journal of Marine and Petroleum Geology 18, 287-306. 
Veizer, J., Ala, D., Azmy, K., Bruckschen, P., Buhl, D., Bruhn, F., Garden, G.A.F., Diener, A., Ebneth, S., Godderis, Y., Jasper, T., Korte, C., Pawellek, F., Podlaha, O.G. Strauss, H., 1999. ${ }^{87} \mathrm{Sr} /{ }^{86} \mathrm{Sr}, \delta^{13} \mathrm{C}$ and $\delta^{18} \mathrm{O}$ evolution of Phanerozoic seawater. Chemical Geology, 161, 59-88.

Worden, R.H., Smalley, P.C., 1996. $\mathrm{H}_{2}$ S-producing reactions in deep carbonate gas reservoirs: Khuff Formation, Abu Dhabi. Chemical Geology, 133, 157-171.

Worden, R.H., Smalley, P.C., Oxtoby, N.H., 1995. Gas souring by thermochemical sulfate reduction at $140^{\circ} \mathrm{C}$. AAPG Bulletin, 79, 854-863.

Worden, R.H., Smalley, P.C., Oxtoby, N.H., 1996. The effects of thermochemical sulfate reduction upon formation water salinity and oxygen isotopes in carbonate gas reservoirs. Geochimica et Cosmochimica Acta, 60, 3925-3931.

Worden, R.H., Smalley, P.C., Oxtoby, N.H., 1998. Reply to the Comment by HG Machel on" The effects of thermochemical sulfate reduction upon formation water salinity and oxygen isotopes in carbonate reservoirs". Geochimica et Cosmochimica Acta, 62, 343-346.

Worden, R.H., Smalley, P.C., Cross, M.M., 2000. The influence of rock fabric and mineralogy on thermochemical sulfate reduction: Khuff Formation, Abu Dhabi. Journal of Sedimentary Research, 70, 1210-1221.

Worden, R. H., Carrigan, W. J., Jones, P. J., 2004. Origin of $\mathrm{H}_{2} \mathrm{~S}$ in Khuff reservoirs by thermochemical sulfate reduction: Evidence from fluid inclusions. Saudi Aramco Journal of Technology, 43, 42-52.

Yang, C., Hutcheon, I., Krouse, H.R., 2001. Fluid inclusion and stable isotopic studies of thermochemical sulphate reduction from Burnt Timber and Crossfield East gas fields in Alberta, Canada. Bulletin of Canadian Petroleum Geology, 49, 149-164.

Zeeh, S., Bechstädt, T., McKenzie, J., Richter, D.K., 1995. Diagenetic evolution of the Carnian Wetterstein platforms of the Eastern Alps. Sedimentology, 42, 199-222. 